\title{
Participatory characterization of the performance of corn landraces and commercial varieties with family farmers
}

\section{Caracterização participativa do desempenho de variedades de milho crioulo e variedades comerciais com agricultores familiares}

\author{
Fillipe Silveira Marini ${ }^{1 *}$, Jefferson Santos Alves da Costa ${ }^{2}$, Maria José Ramos da Silva ${ }^{3}$, Aline \\ Carneiro de Paula ${ }^{3}$, Ivane de Pontes Moura ${ }^{3}$
}

\begin{abstract}
The objective of this study was to compare the performance of landraces and commercial varieties to identify which variety is the most suitable for family farmers. The experimental design was a completely randomized block design with three replicates and 10 varieties. Qualitative and quantitative parameters were evaluated in the useful plot. The qualitative analyses were performed in the field with the participation of farmers, who scored the evaluated parameters as 1 - poor, 2 - average, 3 - good, or 4 excellent. Quantitative analyses were performed without the participation of farmers. The data obtained (qualitative and quantitative) were subjected to analysis of variance, and the means were compared by the Scott-Knott test $(\mathrm{p}<0.05)$. The Pontinha and Adelaide varieties had the best quality variables in the farmers' view. In the quantitative analysis, the landrace varieties showed similar results to the commercial varieties, but the highest yields were obtained with Pontinha and Adelaide. The results of the qualitative and quantitative assessments reaffirm the importance of farmers' knowledge of corn cultivation in the studied municipality.
\end{abstract}

Keywords: Agroecosystem; Agroecology; Family farming; Traditional knowledge; Zea mays.

\section{RESUMO}

O objetivo deste trabalho foi o de comparar o desempenho das variedades crioulas com as variedades comercias, identificando qual variedade é a mais adequada para os agricultores familiares. $\mathrm{O}$ delineamento experimental utilizado foi o de blocos inteiramente casualizado com três repetições e 10 variedades. Na parcela útil foram avaliados parâmetros qualitativos e quantitativos de produção do milho. As análises qualitativas foram realizadas em dias de campo com a participação de agricultores (as), com os quais avaliaram as seguintes notas (1-fraco, 2-médio, 3-bom e 4-ótimo). As análises quantitativas foram realizadas sem a participação dos agricultores. Os dados obtidos (qualitativos e quantitativos) foram submetidos à análise de variância e as médias comparadas pelo teste de Scott-Knott $(\mathrm{p}<0,05)$. As variedades Pontinha e Adelaide foram as melhores na concepção dos agricultores para as variáveis de qualidade. $\mathrm{Na}$ análise quantitativa as variedades crioulas apresentaram resultados semelhantes às comercias, entretanto as maiores produções foram do Pontinha e Adelaide. Os resultados apresentados na

${ }^{1}$ Universidade Federal da Paraíba/CCEN/Programa de Pós-Graduação em Ciências Agrárias (PPGCAG).*E-mail: fsmarini@yahoo.com.br.

${ }^{2}$ Universidade Federal da Paraíba/CCHSA.

${ }^{3}$ Universidade Federal da Paraíba/CCHSA/PPGCAG. 
avaliação qualitativas e quantitativas reafirmam a importância dos saberes dos agricultores(as) no cultivo dos milhos no município estudado.

Palavras-chave: Agroecossistemas; Agroecologia; Agricultura familiar; Saberes tradicionais; Zea mays.

\section{INTRODUÇÃO}

The Corn (Zea mays L.) is one of the most important food sources in the world, has a wide variety of applications in both human and animal food, is of great social and economic importance, and is a basic raw material for the production of various other types of food. Corn cultivation is widespread in the Brazilian Northeast region, constituting a relevant factor for the region's economy. In the state of Paraíba, this plant is present in all microregions and is considered one of the basic crops for the survival of farming families. Corn is highly relevant in family agroecosystems since the whole plant is used, from the most valuable product (grain) to the crop residues (husk, stalk, cob) that go into animal feed, enhancing the profitability of agroecosystems and promoting the self-sufficiency of the production unit (CRUZ et al., 2011).

Northeastern family farmers still practice activities passed from parents to offspring, such as selecting and conserving landrace seeds of various species, including corn, for their perpetuation and annual cultivation. According to Trindade (2006), this technique of storing seeds from one harvest to another, letting them avoid purchasing commercial seeds for planting, gives family farmers autonomy and thus contributes to food security. According to Castelli and Wilkson (2002), the use of landrace seeds represents the accumulation of traditional knowledge, i.e., knowledge created collectively and continuously modified, adapted, and constructed based on existing knowledge and passed from one generation to another.

Year after year, landrace seeds acquire resistance traits and adapt to their growing environments, which leads the species to maintain its genetic characteristics. However, the occurrence of strong short mini-droughts ("veranicos") with irregular rainfall distribution is characteristic of the agreste and semiarid region of Brazil, which, according to some researchers, prevents good yield. Such environmental limitations cause partial or total loss of planting seeds, leaving farmers at the mercy of shortsighted public policies (SILVA et al., 2011). 
The varieties distributed by Brazilian public policies are commercial and do not include the diversity that makes up the regional family agroecosystems of Brazil. Often, only one corn variety and one bean variety are distributed, which are not adapted to the reality of family farmers. This leads to low yields and, especially, the loss of local varieties, thus creating a vicious cycle of dependence on these seed distribution welfare policies. In this sense, the landrace varieties of arid and semiarid regions of Brazil should be valued because they are adapted to the local environmental conditions and thus can produce quality crops and meet local needs. According to Almekinders et al. (2007), the preservation of local agrobiodiversity is paramount and should be stressed and valued. For this, it is necessary to define strategies to facilitate access to landrace seeds and stimulate diversified seed production through public policies.

Given the above, landrace seeds are the ones that best adapt to each region, are more resistant, and are less dependent on inputs, since they have improved through natural selection, through which the most vigorous individuals have persisted (TRINDADE, 2006). Landrace seeds also ensure food diversity and contribute to biodiversity within production systems, which are the basis for sustainability.

The objective of this study is to compare the performance of landrace varieties and commercial varieties to identify which are most suitable for family farmers.

\section{MATERIAL AND METHODS}

The experiment was conducted at the experimental site of the Agriculture Sector of the Center for Humanities and Social and Agrarian Sciences (Centro de Ciências Humanas Sociais e Agrárias), Federal University of Paraíba (Universidade Federal da Paraíba), Campus III, located in Bananeiras, Paraíba state, Brazil, at coordinates $6^{\circ} 46^{\prime} \mathrm{S}$ and $35^{\circ} 38^{\prime} \mathrm{W}$ and $617 \mathrm{~m}$ altitude. The climate of the region is tropical rainy, hot, and humid and is characterized by a maximum temperature of $38{ }^{\circ} \mathrm{C}$ and a minimum temperature of $18{ }^{\circ} \mathrm{C}$, with most rainfall from autumn to winter, concentrated in May to August (EMBRAPA, 1999).

To perform the study, it was necessary to collect corn seeds from the farmers who were guardians of the landrace seeds of the respective studied varieties. These farmers plant, select, and store the studied varieties from one year to the next, thereby 
performing the maintenance of this genetic resource. The commercial varieties were purchased from a commercial farm supplier in the region.

Before the implementation of the experiment, soil samples were collected from the 0-20-cm-depth layers and subjected to fertility analysis. To prepare the site, mechanized plowing was performed, followed by liming according to the soil analysis. After approximately 30-40 days, the site was marked, with a spacing of $0.5 \times 1.0 \mathrm{~m}$, followed by sowing of the varieties, which occurred in the rainy season. For this, holes were made using a hoe, and five seeds were sown per hole. Thinning was performed at 28 days after germination, leaving two plants per hole.

The experimental design was a completely randomized block design with three replicates of 10 varieties (eight landrace varieties, one hybrid, and one commercial variety). The following varieties (treatments) were used: landraces: Adelaide, Branco, Epamil, Hibra, Jabatão, Pontinha, Sabugo Fino, and Teti; commercial hybrids: AG 1051 and BRS Caatingueiro. Each experimental plot was $12 \mathrm{~m}^{2}$, measuring $6.0 \times 2.0 \mathrm{~m}$. There were three rows of corn ( 72 plants), with the central row (20 plants) considered the useful plot.

The cultivation practices performed in the experiment were manual weeding to avoid competition by weeds with the crop. For the phytosanitary control of fall armyworm (Spodoptera frugiperda), three applications of Neem oil (Azadirachta indica) were performed every 7 days at $250 \mathrm{ml}$ per 20 liters of water.

During crop development, before harvest, a qualitative assessment was performed with the participation of family farmers when the plants reached full grain maturation. Each plot was identified by a code (number from 1 to 10) so the family farmer would be blinded to the identity of each genotype at the time of assessment. The following variables were evaluated: plant height (PH), husk yield (HY), ear formation (EFR), and ear filling (EFL). This assessment consisted only of the visual appearance; the farmers were not allowed to remove the ears, so that they could be used in later assessments. Three groups of farmers were formed, and in each treatment observed, they gave scores from 1 to 4 ( 1 - poor, 2 - average, 3 - good, and 4 - excellent) based on their experience and their knowledge of each variable studied (Figure 1). 
Figure 1 - Qualitative assessment by family farmers in a comparative trial of corn varieties carried out in Bananeiras, Paraíba, Brazil, in the 2012 agricultural year.

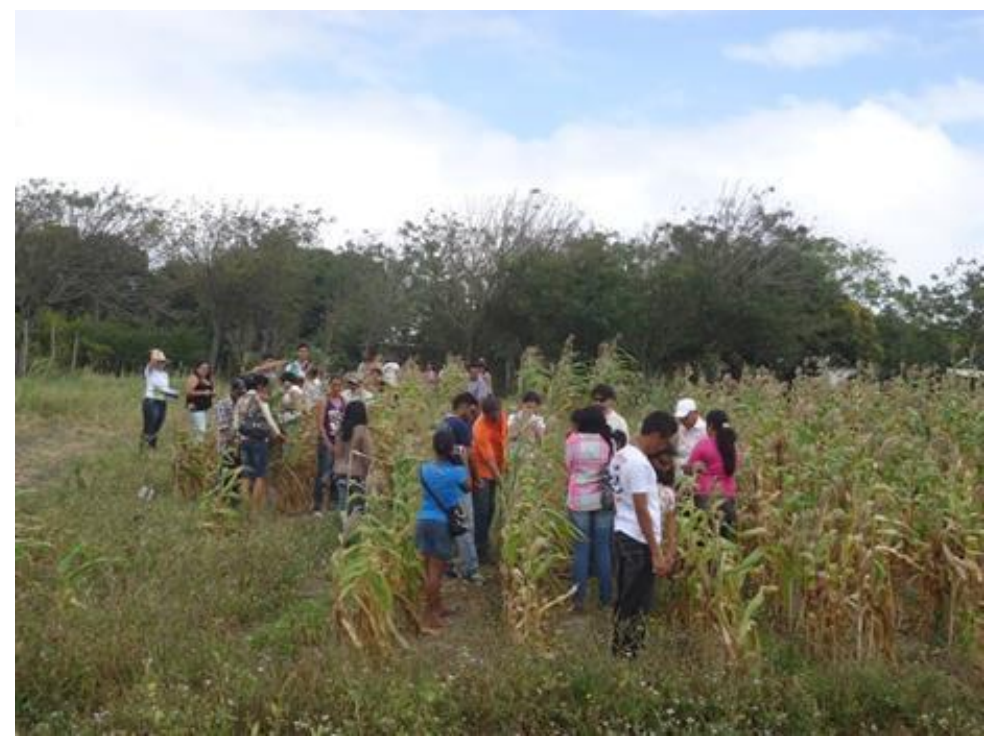

Fonte: Marini and Silva (2012)

A quantitative assessment was performed at harvest time, where the following variables were studied: PH (from the soil surface to the end of the tassel), ear insertion (EI) (from the soil surface to the first ear insertion), stalk diameter (SD) (determined in the center of the first node), and number of leaves and number of ears per plant (visually counted). Additional variables collected were ear length with husk, ear length with no husk, ear diameter, cob diameter, number of kernel rows, HY, cob yield, and grain yield. The materials used in the assessments were calipers, a ruler $(30 \mathrm{~cm})$, measuring tape $(5 \mathrm{~m})$, and a precision scale.

After data collection, the results were subjected to analysis of variance at $5 \%$ probability, and the means were compared by the Scott-Knott test using the SASM-Agri statistical software (CANTERI et al., 2001).

\section{RESULTS AND DISCUSSION}

The participatory assessment allowed farmers to exchange knowledge about the studied varieties, as this moment allowed them to reflect on the landrace seeds (multiplication, conservation, and maintenance). This activity aimed to rouse a new perspective on this subject in public managers. 
Many studies show that it is necessary to be careful with the varieties to be distributed by public policies to family farmers, considering the inclusion of landraces in seed distribution plans to strengthen and better adapt to these farmers' production systems, protect agricultural biodiversity, under the perspective and management condition of the family farmer according to their regional reality (SANTOS et al., 2019; PEREIRA et al., 2017).

Figure 2 - Perception of farmers and farmers' children about corn varieties in a comparative assessment of corn varieties carried out in Bananeiras, Paraíba, Brazil, in the 2012 agricultural year.

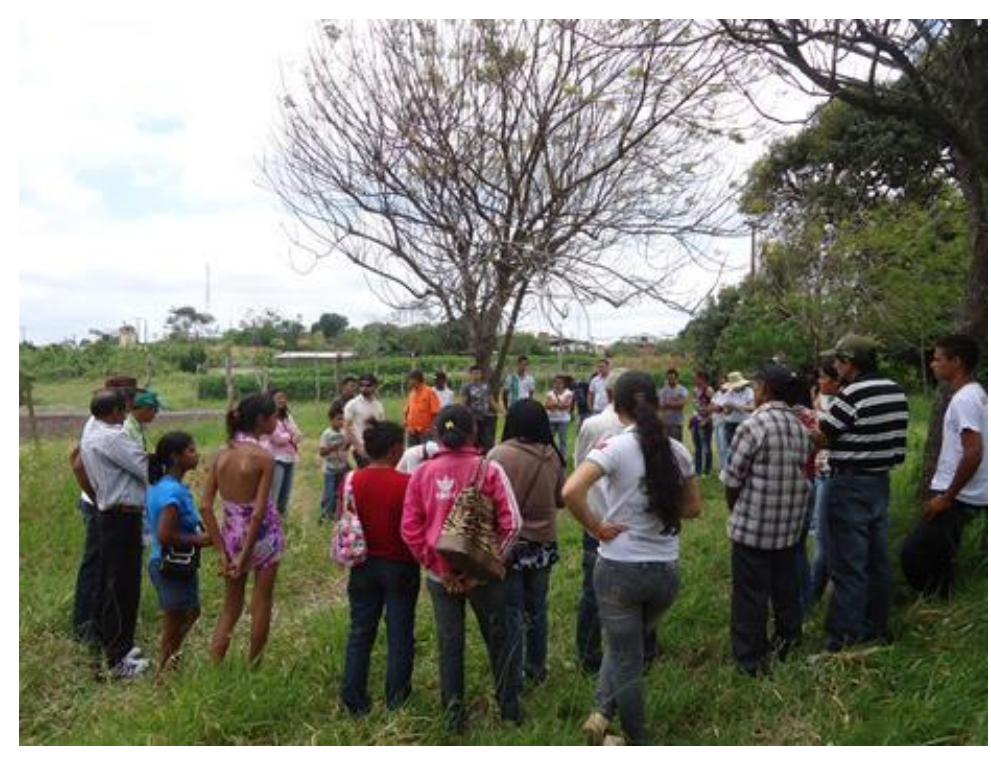

Fonte: Marini and Silva (2012)

The participation of farmers in this process of characterizing the varieties is the main pillar in the search for the appreciation of local and regional knowledge and the improvement of agroecological principles in agroecosystems, in addition to the constant effort to preserve biodiversity and the food security of a people. This participatory method allowed dialogue with the farming families, who could point out the main characteristics of corn plants that were most important to family farmers and assert that these characteristics should be valued and used as support for the development of possible seed public policies.

According to the results presented in Table 1, PH and HY were significantly different at the $5 \%$ probability level by the $\mathrm{F}$ test between treatments, according to the family farmers. 
Table 1 - Mean plant height (PH), husk yield (HY), ear formation (EFR), and ear filling (EFL) at the green point, by assigning scores ( 1 - poor; 2 - average; 3 - good and 4 - excellent) in a comparative and participatory assessment of corn varieties conducted in Bananeiras, Paraíba, in the 2012 agricultural year.

\begin{tabular}{lcccc}
\hline VARIETY & PH & HY & EFR & EFL \\
\hline Adelaide & $2.44 \mathrm{a}$ & $2.66 \mathrm{a}$ & $2.44 \mathrm{a}$ & $2.44 \mathrm{a}$ \\
AG 1051 & $1.55 \mathrm{~b}$ & $2.22 \mathrm{a}$ & $1.89 \mathrm{a}$ & $1.89 \mathrm{a}$ \\
Branco & $2.44 \mathrm{a}$ & $2.44 \mathrm{a}$ & $1.55 \mathrm{a}$ & $1.55 \mathrm{a}$ \\
BRS Caatingueiro & $1.00 \mathrm{~b}$ & $1.00 \mathrm{~b}$ & $1.33 \mathrm{a}$ & $1.22 \mathrm{a}$ \\
Epamil & $2.89 \mathrm{a}$ & $2.44 \mathrm{a}$ & $2.44 \mathrm{a}$ & $1.78 \mathrm{a}$ \\
Hibra & $2.33 \mathrm{a}$ & $2.22 \mathrm{a}$ & $1.66 \mathrm{a}$ & $1.66 \mathrm{a}$ \\
Jabatão & $2.33 \mathrm{a}$ & $2.78 \mathrm{a}$ & $1.89 \mathrm{a}$ & $2.22 \mathrm{a}$ \\
Pontinha & $2.22 \mathrm{a}$ & $2.55 \mathrm{a}$ & $2.00 \mathrm{a}$ & $2.00 \mathrm{a}$ \\
Sabugo Fino & $2.22 \mathrm{a}$ & $2.11 \mathrm{a}$ & $1.55 \mathrm{a}$ & $2.00 \mathrm{a}$ \\
Teti & $2.00 \mathrm{a}$ & $2.55 \mathrm{a}$ & $1.44 \mathrm{a}$ & $1.33 \mathrm{a}$ \\
\hline MEAN & $\mathbf{2 . 1 4}$ & $\mathbf{2 . 2 9}$ & $\mathbf{1 . 8 1}$ & $\mathbf{1 . 8 0}$ \\
CV $(\%)$ & 23.05 & 24.63 & 33.46 & 29.43 \\
\hline
\end{tabular}

Means in columns followed by the same letter do not differ significantly by the Scott-Knott test $\mathrm{p}<0.05$.

In the farmers' view of $\mathrm{PH}$, the commercial varieties BRS Caatingueiro and AG 1051 were considered poor, whereas the landrace varieties Adelaide, Branco, Epamil, Hibra, Jabatão, Pontinha, Sabugo Fino, and Teti were considered average, that is, they had the tallest heights. In HY, only the BRS Caatingueiro variety was considered poor by the family farmers, and the others were considered average. Cruz et al. (2006) observed that taller plants are advantageous, especially when used for the preparation of animal feed, where the whole plants is used for ensiling, and for their greater production of organic matter for soil cover, corroborating the view of the family farmers who participated in the study. As well as Santos et al. (2019) when studying, together with farmers, the variety BRS Caatingueiro and landraces, the species BRS was not shown to be suitable for grain production. In this sense, it can be seen that the BRS Caatingueiro variety, which is widely distributed by the government's seed program in the region, does not meet the demand of farmers for use in animal feed or the supply of organic matter to the soil. Therefore, it is not advisable to plant this variety in the region and distribute it through social programs, whether municipal or state.

This result is worrisome for family farmers, especially in the semiarid region. This is because corn is needed as a resource for food security. Food security comes not only from the seeds and varieties that are being preserved but also the grain for sale and the husk for animal feed as silage in times of scarce rainfall. For Pagliosa et al. (2015), 
the landraces varieties should be used first, under non-ideal growing conditions, because as they are economically beneficial to producers, as they require low investment due to the low price of seeds, have high genetic variability and greater tolerance to variations environmental issues.

Although leaves, husk, and cob are reused for animal feed, the size of the ears and consequently the formation and size of the seeds are the fundamental criteria for choosing a variety and for its cultivation, management, mass selection, conservation, and maintenance. Although there was no significance at $5 \%$ probability by the F test, there was a tendency among the farmers to score the variables EFR and EFL in the landrace varieties Adelaide and Pontinha as average and good and the others as poor, except for EPAMIL in EFR and Jabatão and Sabugo Fino in EFL.

Among the landrace varieties, the one deemed best by the farmers was the Pontinha variety, as it had the characteristic of complete ear filling up to the tip, which was strongly stressed by the guardian farmers, who reported it to be more productive and heavier on a dry-weight basis, giving it good income potential. The present study found that landrace varieties have higher quality than commercial varieties in terms of meeting the demands and needs of family farmers. Thus, the knowledge of family farmers should be made part of the agenda in the discussion and identification of the best production characteristics of varieties of corn and other crops, especially regarding the issue of seed distribution through social programs in the country.

At harvest time, a quantitative assessment of the development of the studied varieties was performed without the participation of family farmers. We observed that there was no significant difference at the $5 \%$ probability level by the $\mathrm{F}$ test in the analyzed variables, including $\mathrm{PH}$, EI, and SD, though the number of leaves was significantly different between some varieties.

It was observed that the variables $\mathrm{PH}$ and ear insertion did not differ between the varieties, which were similar in this attribute. However, it is common for landrace varieties to have taller heights than commercial varieties, which confers them good acceptability by farmers. It was observed that all landraces and the commercial varieties BRS Caatingueiro and AG 1051 (double hybrid) showed lower PH (1.70 to $1.90 \mathrm{~m}$ ) and EI values $(0.70$ to $0.90 \mathrm{~m})$ than recommended in Brazil, according to Carvalho et al. (2004), and lower-than-recommended AP (-2.60 m) and EI (-1.60 m) values, according to Cruz et al. (2010). 
Table 2 - Mean plant height (PH), ear insertion (EI), stalk diameter (SD), and number of leaves (NL) of corn varieties in the comparative assessment conducted in the municipality of Bananeiras, Paraíba, in 2012.

\begin{tabular}{lcccc}
\hline VARIETY & $\begin{array}{c}\text { PH } \\
(\mathbf{m})\end{array}$ & $\begin{array}{c}\text { EI } \\
(\mathbf{m})\end{array}$ & $\begin{array}{c}\text { SD } \\
(\mathbf{c m})\end{array}$ & NL \\
\hline Adelaide & $1.42 \mathrm{a}$ & $0.58 \mathrm{a}$ & $14.06 \mathrm{a}$ & $13.30 \mathrm{a}$ \\
Branco & $1.48 \mathrm{a}$ & $0.62 \mathrm{a}$ & $16.27 \mathrm{a}$ & $13.40 \mathrm{a}$ \\
BRS Caatingueiro & $1.17 \mathrm{a}$ & $0.29 \mathrm{a}$ & $11.77 \mathrm{a}$ & $9.43 \mathrm{c}$ \\
Epamil & $1.37 \mathrm{a}$ & $0.50 \mathrm{a}$ & $14.14 \mathrm{a}$ & $14.11 \mathrm{a}$ \\
Hibra & $1.31 \mathrm{a}$ & $0.49 \mathrm{a}$ & $14.84 \mathrm{a}$ & $12.56 \mathrm{~b}$ \\
Jabatão & $1.51 \mathrm{a}$ & $0.58 \mathrm{a}$ & $15.29 \mathrm{a}$ & $13.81 \mathrm{a}$ \\
Pontinha & $1.45 \mathrm{a}$ & $0.57 \mathrm{a}$ & $15.54 \mathrm{a}$ & $13.01 \mathrm{~b}$ \\
Sabugo Fino & $1.51 \mathrm{a}$ & $0.61 \mathrm{a}$ & $14.76 \mathrm{a}$ & $12.83 \mathrm{~b}$ \\
Teti & $1.29 \mathrm{a}$ & $0.51 \mathrm{a}$ & $16.35 \mathrm{a}$ & $13.30 \mathrm{a}$ \\
AG 1051 & $1.31 \mathrm{a}$ & $0.45 \mathrm{a}$ & $15.16 \mathrm{a}$ & $12.58 \mathrm{~b}$ \\
\hline MEAN & $\mathbf{1 . 3 8}$ & $\mathbf{0 . 5 2}$ & $\mathbf{1 4 . 1 8}$ & $\mathbf{1 2 . 8 3}$ \\
CV $(\%)$ & 10.81 & 16.68 & 10.04 & 3.33 \\
\hline
\end{tabular}

Means in columns followed by the same letter do not differ significantly by the Scott-Knott test $\mathrm{p}<0.05$.

The number of leaves was higher for the varieties Adelaide, Branco, Epamil, Jabatão, and Teti than Hibra, Pontinha, Sabugo Fino, AG 1051, and BRS Caatingueiro. This last variety had the worst result in this regard. The foliage of corn plants is highly important for family farmers, as it is part of animal feed during times of scarce rainfall. According to Santos et al. (2011), corn is used in its entirety: leaves, ear, cob, and grains. Given this result, although the BRS Caatingueiro variety has strong characteristics such as precocity, which allows good yields in periods of drought (Carvalho et al., 2004), it does not meet the husk yield requirement, making it insufficient for the reality of farmers in the semiarid region. According to Santos et al. (2011), this is because BRS Caatingueiro seeds are obtained in a production system with high use of inputs such as pesticides and chemical fertilizers, in addition to irrigation, which is very different from the reality of family farmers.

There was no significant difference in SD among the varieties studied. This is important when intercropping is desired. This is a tradition of family farmers in the semiarid region of Paraíba for better use of their area, given they have small areas for planting.

According to Santos and Tivelli (2017), it is still difficult to acquire quality seeds in organic systems that have not been chemically treated. Thus, the landraces varieties, which have local adaptations and are stored organically, are cultivated by traditional farmers who carry out a genetic improvement process by mass selection, that 
is, selecting the best ears of plants with ideal characteristics to be able to increase each productivity.

When comparing the qualitative and quantitative assessments, the knowledge of the family farmers is appreciated, as their choice agreed with the quantitative assessment, demonstrating the close relationship they have with their genetic material. The conservation, management, cultivation, and selection of landrace varieties is a virtue of family farmers, as this resource is used to support the family, diversify their property, and, in particular, maintain local biodiversity.

The Table 3 lists some studied variables that were not significantly different at the $5 \%$ probability level by the $\mathrm{F}$ test between the treatments.

Table 3 - Mean ear diameter (ED), cob diameter (CD), ear length with husk (ELH), ear length with no husk (ELNH), and number of kernel rows (NKR) of the corn varieties in the comparative assessment conducted in the municipality of Bananeiras, Paraíba, in 2012.

\begin{tabular}{lccccc}
\hline VARIETIES & $\begin{array}{c}\text { ED } \\
(\mathbf{m m})\end{array}$ & $\begin{array}{c}\text { ELH } \\
(\mathbf{c m})\end{array}$ & $\begin{array}{c}\text { ELNH } \\
(\mathbf{c m})\end{array}$ & NKR & $\begin{array}{c}\text { CD } \\
(\mathbf{m m})\end{array}$ \\
\hline Adelaide & $34.15 \mathrm{a}$ & $20.23 \mathrm{a}$ & $9.74 \mathrm{a}$ & $8.59 \mathrm{a}$ & $19.33 \mathrm{a}$ \\
AG 1051 & $27.58 \mathrm{a}$ & $17.01 \mathrm{a}$ & $7.60 \mathrm{a}$ & $9.67 \mathrm{a}$ & $17.77 \mathrm{a}$ \\
Branco & $32.46 \mathrm{a}$ & $19.36 \mathrm{a}$ & $9.06 \mathrm{a}$ & $8.99 \mathrm{a}$ & $18.47 \mathrm{a}$ \\
BRS Caatingueiro & $28.8 \mathrm{a}$ & $16.37 \mathrm{a}$ & $7.45 \mathrm{a}$ & $9.88 \mathrm{a}$ & $17.95 \mathrm{a}$ \\
Epamil & $30.68 \mathrm{a}$ & $18.90 \mathrm{a}$ & $8.21 \mathrm{a}$ & $9.24 \mathrm{a}$ & $16.70 \mathrm{a}$ \\
Hibra & $30.59 \mathrm{a}$ & $19.07 \mathrm{a}$ & $8.92 \mathrm{a}$ & $10.43 \mathrm{a}$ & $18.87 \mathrm{a}$ \\
Jabatão & $30.89 \mathrm{a}$ & $19.21 \mathrm{a}$ & $7.74 \mathrm{a}$ & $9.57 \mathrm{a}$ & $19.78 \mathrm{a}$ \\
Pontinha & $41.14 \mathrm{a}$ & $18.90 \mathrm{a}$ & $9.88 \mathrm{a}$ & $10.14 \mathrm{a}$ & $17.02 \mathrm{a}$ \\
Sabugo Fino & $29.63 \mathrm{a}$ & $19.00 \mathrm{a}$ & $9.54 \mathrm{a}$ & $9.90 \mathrm{a}$ & $15.43 \mathrm{a}$ \\
Teti & $29.48 \mathrm{a}$ & $19.18 \mathrm{a}$ & $8.12 \mathrm{a}$ & $8.52 \mathrm{a}$ & $19.33 \mathrm{a}$ \\
\hline MEAN & $\mathbf{3 1 . 5 4}$ & $\mathbf{1 8 . 7 2}$ & $\mathbf{8 . 6 3}$ & $\mathbf{9 . 4 9}$ & $\mathbf{1 8 . 0 7}$ \\
CV $(\%)$ & 19.83 & 10.67 & 18.99 & 13.33 & 14.93 \\
\hline
\end{tabular}

Means in columns followed by the same letter do not differ significantly by the Scott-Knott test $\mathrm{p}<0.05$.

The results for ears are interesting because the commercial varieties underwent a genetic improvement process and were developed for production purposes, so it was expected that they would have long ears, with good diameter and uniform rows. However, they had similar traits to the landrace varieties. Silva et al. (2015), when comparing traditional cultivars with hybrids, observed low yield potential of ears, which may be due to open pollination.

This result may be related to the fact that landrace seeds are adapted to climatic irregularities and are produced in low-fertility soils, among other reasons. According to Trindade (2006), landrace seeds are the ones that best adapt to each region, are more resistant and depend less on inputs, since they have improved through natural selection, 
in which the most vigorous individuals persist. Commercial varieties only show their full productive potential when rainfall and fertility conditions are favorable to them, which does not match the reality of family farmers, who lack capital to invest in certain inputs and irrigation.

The results presented in Table 4 were not significantly different between varieties at the $5 \%$ probability level by the $\mathrm{F}$ test.

Table 4 - Mean ear yield (EY), husk yield (HY), cob yield (CY), and grain production (GY) of corn varieties in the comparative assessment conducted in the municipality of Bananeiras, Paraíba, in 2012.

\begin{tabular}{lcccc}
\hline VARIETY & $\begin{array}{c}\text { EY } \\
\text { kg per } \\
\text { treatment }\end{array}$ & $\begin{array}{c}\text { HY } \\
\text { g plant }^{-1}\end{array}$ & $\begin{array}{c}\text { CY } \\
\text { g plant }^{-1}\end{array}$ & $\begin{array}{c}\text { GY } \\
\text { kg.ha-1 }\end{array}$ \\
\hline Adelaide & $1.08 \mathrm{a}$ & $151.38 \mathrm{a}$ & $143.33 \mathrm{a}$ & $473.73 \mathrm{a}$ \\
AG 1051 & $1.00 \mathrm{a}$ & 123.60 & $100.42 \mathrm{a}$ & $354.53 \mathrm{a}$ \\
Branco & $1.20 \mathrm{a}$ & $127.77 \mathrm{a}$ & $139.45 \mathrm{a}$ & $409.14 \mathrm{a}$ \\
BRS Caatingueiro & $0.95 \mathrm{a}$ & $95.82 \mathrm{a}$ & $97.24 \mathrm{a}$ & $312.96 \mathrm{a}$ \\
Epamil & $0.85 \mathrm{a}$ & $113.88 \mathrm{a}$ & $98.03 \mathrm{a}$ & $260.81 \mathrm{a}$ \\
Hibra & $1.00 \mathrm{a}$ & $123.60 \mathrm{a}$ & $121.42 \mathrm{a}$ & $400.23 \mathrm{a}$ \\
Jabatão & $1.03 \mathrm{a}$ & $110.97 \mathrm{a}$ & $92.17 \mathrm{a}$ & $278.94 \mathrm{a}$ \\
Pontinha & $1.16 \mathrm{a}$ & $165.27 \mathrm{a}$ & $125.45 \mathrm{a}$ & $509.94 \mathrm{a}$ \\
Sabugo Fino & $1.05 \mathrm{a}$ & $131.94 \mathrm{a}$ & $108.61 \mathrm{a}$ & $439.89 \mathrm{a}$ \\
Teti & $1.03 \mathrm{a}$ & $130.55 \mathrm{a}$ & $95.29 \mathrm{a}$ & $277.86 \mathrm{a}$ \\
\hline MEAN & $\mathbf{1 . 0 3}$ & $\mathbf{1 2 7 . 4 7}$ & $\mathbf{1 3 3 . 4 9}$ & $\mathbf{3 7 1 . 9 0}$ \\
CV $(\%)$ & 9.44 & 39.47 & 51.70 & 54.22 \\
\hline Means & in & &
\end{tabular}

Means in columns followed by the same letter do not differ significantly by the Scott-Knott test $\mathrm{p}<0.05$.

Both the landrace and commercial varieties showed similar results for the variables cited above. In terms of grain yield, Paterniani et al. (2000) stated that landrace varieties are less productive than commercial cultivars. However, under the conditions of this study, the results did not differ between the varieties. Carvalho et al. (2000) evaluated the adaptability and stability of corn cultivars in Northeast Brazil and found that corn hybrids in general perform better than corn varieties.

The mean yield for the corn varieties was lower than the national average for the 2011/2012 crop season $\left(4,799 \mathrm{~kg} \cdot \mathrm{ha}^{-1}\right)$, whereas the estimated yield for the Northeast region in these harvests was $1,802\left(\mathrm{~kg} \cdot \mathrm{ha}^{-1}\right)$, higher than that obtained among the most productive varieties; however, all varieties reached higher yields than the average for the state of Paraíba, which has been estimated at $106 \mathrm{~kg} \cdot \mathrm{ha}^{-1}$ (CONAB, 2012). The landrace varieties Pontinha $\left(509.94 \mathrm{~kg} \cdot \mathrm{ha}^{-1}\right)$, Adelaide (473.73 $\left.\mathrm{kg} \cdot \mathrm{ha}^{-1}\right)$, Sabugo Fino

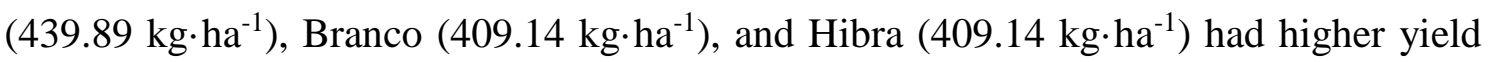


than the BRS Caatingueiro $\left(312.96 \mathrm{~kg} \cdot \mathrm{ha}^{-1}\right)$ and AG 1051 commercial varieties $(354.53$ $\left.\mathrm{kg} \cdot \mathrm{ha}^{-1}\right)$.

According to Altieri (2004), the landrace varieties cultivated by farmers year after year have greater adaptability to the edaphoclimatic conditions of the region; thus, in years with low rainfall, they stand out compared to commercial varieties that generally need favorable environments and production technologies.

\section{CONCLUSION}

The corn landrace varieties Adelaide and Pontinha showed greater preference than the commercial varieties BRS Caatingueiro and AG 1051 based on the qualitative assessment performed with family farmers from the semiarid region of Paraíba. This result shows the level of acceptance and preference of farmers for their landrace varieties, as they have the characteristics the farmers consider essential for planting their agroecosystems.

The participatory qualitative method used here is an important methodological tool because it allows all participants to present their experiences and to exchange knowledge.

The results of the qualitative and quantitative assessments reaffirm the importance of farmers' knowledge in the selection, preservation, and conservation of landrace seeds. This is fully reflected in the Pontinha and Adelaide varieties, as observed in both assessments, and shows that each individual involved in this study has mastery of their landrace corn crops.

Family farmers have a great genetic variability in their domains, but these seeds are devalued by seed policies.

\section{ACKNOWLEDGMENTS}

We are very grateful to all the families farmers who participated in this work for their technical knowledge and human values. Thanks to ASPTA, EMRAPA Tabuleiros Costeiros and Polo da Borborema, which provided us with an excellent logistical operation in the field and with essential feedback.

\section{DISCLOSURE STATEMENT}

No potential conflict of interest was reported by the authors. 


\section{FUNDING}

This work was supported by the Universidade Federal da Paraíba and CAPES.

\section{REFERÊNCIAS}

ALMEKINDERS, C. J. M; THIELE, G; DANIAL, D. L. Can cultivars from participatory plant breeding improve seed provision to small-scale farmers? Euphytica, 153, p. 363-372, 2007.

ALTIERI, M. Agroecologia: a dinâmica produtiva da agricultura sustentável. 4.ed. Porto Alegre: Editora da UFRGS, 2004. 120p.

CANTERI, M. G., Althaus, R. A., VIRGENS FilHO, J. S., GIGLiOTI, E. D., GODOY, C. V. SAM-AGRI- Sistema para a análise e separação de médias em experimentos agrícolas pelos métodos Scott-Knott, Tukey e Duncan. Revista Brasileira de Agrocomputação, v. 1, n. 2, p. 18-24, 2001.

CARVALHO, H. W. L.; LEAL, M. DE L.DA S.; DOS SANTOS, M. X.; CARDOSO, M. J.; MONTEIRO, A. A. T.; TABOSA, J. N; Adaptabilidade e estabilidade de cultivares de milho no Nordeste Brasileiro. Pesquisa Agropecuária, v. 35, n. 6, p. 1115-1123, 2000.

CARVAlHO, H. W. L.; SANTOS, M. X.; SILVA, A. A. G.; CARDOSO, M. J.; SANTOS, D. M.; TABOSA, J. N.; MICHEREFF FILHO, M.; LIRA, M. A.; BONFIM, M. H. C.; SOUZA, E. M.; SAMPAIO, G. V.; BRITO, A. R. M. B.;DOURADO, V. V.; TAVARES, J. A.; NETO, J. G. N.; NASCIMENTO, M. M. A.; TAVARES FILHO, J. J.; ANDRADE JÚNIOR, A. S.; CARVALHO, B. C. L. Caatingueiro uma variedade de milho para o semiárido nordestino. Aracajú: Embrapa Tabuleiros Costeiros, 2004, 8p. (Comunicado Técnico).

CASTELli, P. G.; WILKINSON, J. Conhecimento tradicional, inovação e direitos de proteção. Rio de Janeiro: Estados, Sociedade e Agricultura. n. 19, p: 89-112, 2002. 
CONAB. Companhia Nacional de Abastecimento. Acompanhamento da safra brasileira de grãos. Safra 2011/2012. Décimo Segundo Levantamento Setembro/2012. Disponível em:www.conab.gov.br.

CRUZ, J. C.; KONZEN, E. A.; PEREIRA FILHO, I. A.; MARRIEL, I. E.; CRUZ, I.; DuARte, J. de O.; OliveirA, M. F. de; AlVARENGA, R. C. Produção de milho orgânico na agricultura familiar. Sete Lagoas: Embrapa Milho e Sorgo, 2006. 17p. (Circular Técnica 81).

CRUZ, J. C.; PEREIRA FILHO, I. A.; ALVARENGA, R. C.; GONTIJO NETO, M. M.; VIANA, J. H. M.; OlIVEIRA, M. F.; MATRANGALO, W. J. R.;

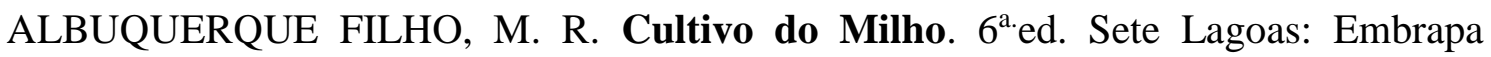
Milho e Sorgo, 2010, 10p.

CRUZ, J. C.; PEREIRA FILHO, I. A.; PIMENTEL, M. A. G.; COELHO, A. M.; KARAM, D.; CRUZ, I.; GARCIA, J. C.; MOREIRA, J.A. A.; OLIVEIRA, M. F. DE; NETO, M. M.G.; ALBUQUERQUE, P. E. P. DE; VIANA, P. A.; MENDES, S. M.; COSTA, R. V. DA; AlvarEnGA, R. C.; MATRANGOLO, W. J.R. Produção de Milho na Agricultura Familiar. Sete Lagoas: Embrapa Milho e Sorgo, 2011, 45p. (Circular Técnica 159).

EMBRAPA. Centro Nacional de Pesquisa de Solos (Rio de Janeiro, RJ). Sistema brasileiro de classificação de solos. Brasília: Embrapa-SPI, 1999. 412 p.

PAGLIOSA, E. S.; CARPENTIERI-PÍPOLO, V.; ZUCARELI, C.; ZAGO, V. S. Análise GGE biplot de genótipos de milho sob diferentes formas de adubação em sistema de agricultura familiar Semina: Ciências Agrárias, v. 36, n. 5, p. 2965-2975. 2015 .

PATERNIANI, E.; NASS, L.L.; SANTOS, M.X. O valor dos recursos genéticos de milho para o Brasil: uma abordagem histórica da utilização do germoplasma. In: UDRY, C.W.; DUARTE, W. (Org.) Uma história brasileira do milho: o valor dos recursos genéticos. Brasília: Paralelo 15, 2000. p.11-41. 
PEREIRA, V. C.; LÓPEZ, P. A.; DAL SOGLIO, F. K. A conservação das variedades crioulas para a soberania alimentar de agricultores: análise preliminar de contextos e casos no Brasil e no México. HOLOS, v. 4, p. 37-55. 2017.

SANTOS, A. S.; CURADO, F. F.; TAVARES, E. D. Pesquisas com sementes crioulas e suas interações com as políticas públicas na região Nordeste do Brasil. Cadernos de Ciência \& Tecnologia, v. 36, n. 3, p. 1-19. 2019

SANTOS, B.C.N.; TIVELLI, W.S. Como produzir milho orgânico? Rio de janeiro: Sociedade Nacional de Agricultura, 2017. $56 \mathrm{p}$

SANTOS, J.F.; GRANGEIRO, J. I. T.; BRITO, L. M. P.; Comportamento de cultivares de milho nas condições edafoclimáticas do brejo paraibano. Engenharia Ambiental. v. 8, n. 4, p. 81-90, 2011.

SILVA, E. D.; SANTOS, A. S.; NUNES, F. R. MARINI, F. S. Pesquisa participativa para avaliação e seleção das Sementes da Paixão junto às famílias agricultoras na Paraíba. Caderno de Agroecologia, v. 6, n. 2, p. 1-5, 2011.

SILVA, G. C.; SCHMITZ, R.; SILVA, L. C.; CARPANINI, G. G.; MAGALHÃES, R. C. Desempenho de cultivares para produção de milho verde na agricultura familiar do sul de Roraima. Revista Brasileira de Milho e Sorgo, v. 14, n. 2, p. 273-282, 2015.

TRINDADE, C. C. Sementes Crioulas e Trangênicas, uma reflexão sobre sua relação com as comunidades tradicionais. In: XV Congresso Nacional do Conpedi, Manaus, p: $15,2006$. 